\title{
Effect of Timing of Fungicide Applications on Development of Rusts on Daylily, Geranium, and Sunflower
}

\author{
D. S. Mueller, University of Georgia, Department of Plant Pathology, Georgia Station, Griffin 30223; S. N. Jeffers, \\ Clemson University, Department of Entomology, Soils, and Plant Sciences, Clemson, SC 29634; and J. W. Buck, \\ University of Georgia, Department of Plant Pathology, Georgia Station, Griffin 30223
}

\begin{abstract}
Mueller, D. S., Jeffers, S. N., and Buck, J. W. 2004. Effect of timing of fungicide applications on development of rusts on daylily, geranium, and sunflower. Plant Dis. 88:657-661.

Integrated disease management should provide the most effective means of controlling rusts on ornamental crops over time, and fungicides are an important component of an integrated rust management program. Proper timing of fungicide applications is critical for effective disease management; however, information about application timing is lacking for rusts on ornamental crops. The objective of this study was to determine how fungicides affected rust development on daylily, geranium, and sunflower plants when applied several days before or after inoculation. Five fungicides registered for use against rusts on ornamental crops were evaluated: the strobilurin azoxystrobin; three sterol biosynthesis inhibiting fungicides-myclobutanil, propiconazole, and triadimefon; and the broad spectrum protectant chlorothalonil. All five fungicides significantly reduced lesion development by rust pathogens on daylily, geranium, and sunflower plants when these compounds were applied preventatively up to 15 days before inoculation and infection with a few exceptions (e.g., propiconazole on geranium and triadimefon on sunflower). Curative activity, which resulted from fungicide application after inoculation, was observed for the three rusts with some products (azoxystrobin on all three plants and myclobutanil, propiconazole, and triadimefon on geranium) when applied up to 7 days postinoculation. In general, fungicide efficacy with several of the products decreased as the time from application to inoculation (preventative activity) or inoculation to application (curative activity) increased.
\end{abstract}

The production of ornamental crops is one of the fastest growing segments of agriculture in the United States. The wholesale value of floriculture crops was almost \$14 billion in 2002 (14). Several diseases, including rusts, can negatively affect the production of ornamentals. Rust pathogens can be easily spread, and under ideal conditions there is a potential for large losses due to reduced plant health and aesthetic value as well as due to possible quarantine restrictions and eradication efforts $(2,9,27,29)$. Rusts have the potential to dramatically affect the production of ornamental crops in the United States because it is difficult to detect rust pathogens on symptomless but contaminated or infected propagation material entering the country or moving state-to-state.

Daylilies (Hemerocallis spp.) and zonal geraniums (Pelargonium $\times$ hortorum) are economically important ornamental crops

Corresponding author: J. W. Buck

E-mail: jbuck@griffin.uga.edu

Current address of D. S. Mueller: Department of Plant Pathology, Iowa State University, Ames 50011.

Accepted for publication 30 January 2004.

Publication no. D-2004-0320-01R

(C) 2004 The American Phytopathological Society that recently have been adversely affected by rusts. Daylily rust caused by the fungus Puccinia hemerocallidis was first reported in the United States in 2001 (30), and this disease restricted plant movement until a federal quarantine was lifted by the U.S. Department of Agriculture-Plant Protection and Quarantine in January 2002. Many of the commercial daylily cultivars in production were susceptible to $P$. hemerocallidis (22), which undoubtedly contributed to the epidemic that occurred nationally. In 1997, geranium production in South Carolina was impacted significantly by rust, caused by Puccinia pelargonii-zonalis (12). Diseased geraniums were found at nurseries and greenhouses, but not before they were distributed to retail outlets around the southeastern United States. Urediniospores of both $P$. hemerocallidis and $P$. pelargonii-zonalis can reinfect the same plant or neighboring plants, leading to epidemics in greenhouses, nurseries, and landscapes. Frequent state-to-state movement of diseased or infested plant material contributed to the impact of both daylily and geranium rusts.

A management plan that incorporates scouting, removal of infected plant material, use of resistant cultivars (when available), and fungicides is recommended to keep rust inoculum pressure low at commercial production sites (15). Fungicides in several chemical classes are effective against rusts on ornamental crops (13), and several, including myclobutanil and propiconazole, have displayed curative properties against several species of Puccinia $(2,6,9)$. To reduce the potential of resistance developing in rust populations, it is recommended that fungicides with different chemistries and, therefore, modes of action, be alternated in a spray program $(4,13)$. In addition, the timing of fungicide applications, with respect to the infection period of rust pathogens, also affects efficacy, but there is little information available on how this influences subsequent development of rusts on ornamental crops.

Fungicide studies on management of rusts typically are conducted in two different ways, either in the field with fungicides being sprayed at regular intervals (i.e., once a week or once every 2 weeks) and disease assessed over time $(16,19,24,31)$ or under controlled environments with fungicides being applied preventatively-i.e., immediately prior to inoculation $(1,4,18,20,25)$. Field studies are more informative but are not as reliable because of environmental factors and may not be feasible because of time and resource restraints. Controlled environment experiments will give immediate results on the efficacy of the fungicide, but by limiting the study to one application timing, they do not provide information on residual and curative activities.

More information is needed on the timing of fungicide applications to better manage rusts on ornamental crops and limit the potential for development of fungicide resistance in pathogen populations. Therefore, the objective of this study was to investigate the effect of timing of fungicide application (i.e., both pre- and postinoculation) on subsequent disease development by the three species of Puccinia that occur on daylily, geranium, and sunflower. Sunflower was included in these studies for comparison purposes because extensive research has been conducted on management of sunflower rust with fungicides $(1,10,16,18,20,25)$ and because of the recent development of several ornamental sunflower cultivars.

\section{MATERIALS AND METHODS}

Pathogen and plant maintenance. $P$. hemerocallidis was maintained on 'Pardon Me' daylilies in a greenhouse with average night/day temperatures of $22 / 26^{\circ} \mathrm{C}$ (4). $P$. 
pelargonii-zonalis was maintained on 'Elite White' geranium (Pelargonium $\times$ hortorum) seedlings in a greenhouse with average night/day temperatures of $19 / 21^{\circ}$ C. An isolate of Puccinia helianthi race 3 was maintained on HA 288 sunflower (Helianthus annuus) seedlings, a confectionery sunflower inbred line susceptible to most races of this pathogen, in a greenhouse with average night/day temperatures of $22 / 26^{\circ} \mathrm{C}$.

Plants of the daylily cultivar 'LeeBea Orange Crush', susceptible to daylily rust (22), were grown in Metro-Mix 400 (The Scotts Company, Marysville, $\mathrm{OH}$ ) in 3.8liter pots in a rust-free greenhouse. Plants were irrigated as needed and fertilized with Osmocote Plus 15-9-12 controlled release fertilizer (The Scotts Co.). 'Elite White' geraniums and sunflower inbred line HA 288 were seeded in $3.7 \times 5.8 \mathrm{~cm}$ six-packs (TFI Polyform, Inc., Plymouth, MN) in Metro-Mix 360 (The Scotts Co.) and placed in a greenhouse with average night/day temperatures of $24 / 28^{\circ} \mathrm{C}$ for 4 to 6 weeks.

Plant inoculations and fungicide applications. Urediniospores of each rust species were collected from actively sporulating pustules using a vacuum spore collector, suspended in $0.05 \%$ Tween 20 (J. T. Baker, Phillipsburg, NJ), and filtered through five layers of sterile cheesecloth (21). Spores were enumerated using a hemacytometer and then diluted to 2 to $4 \times$ $10^{5}$ spores per milliliter in $0.05 \%$ Tween 20. All urediniospore suspensions were used within $30 \mathrm{~min}$ of preparation. Plants were watered immediately prior to inoculation, sprayed with a urediniospore suspension until runoff, placed in plastic bags to maintain high relative humidity, and stored in the dark at $23^{\circ} \mathrm{C}$ (daylilies and sunflowers) and $20^{\circ} \mathrm{C}$ (geraniums) (4,21). Bags were removed after $24 \mathrm{~h}$, and daylily and sunflower plants were placed in a research greenhouse with average night/day temperatures of $22 / 26^{\circ} \mathrm{C}$, while geraniums were placed in a greenhouse with average night/day temperatures of $19 / 21^{\circ} \mathrm{C}$. Foliage on all plants was kept dry for the remainder of each experiment.
Five fungicides (one broad spectrum protectant, one strobilurin, and three sterol biosynthesis inhibiting compounds [SBI]) labeled for rust management on ornamental crops were used in all experiments at the maximum recommended rates on product labels (Table 1). Each fungicide was suspended in tap water and applied to runoff with a hand-held spray bottle. All plants were sprayed with fungicides, and then one set of plants (three replicates) was inoculated $1 \mathrm{~h}, 1,5,10$, or 15 days later (corresponding to 15, 10, 5, 1 day, and $1 \mathrm{~h}$ preinoculation). At each time interval, plants were inoculated with a freshly prepared urediniospore suspension. One set of plants in each time interval was not treated with fungicides (control) to account for possible differences in inoculum viability. Daylily and sunflower leaves treated 15, 10 , and 5 days preinoculation were marked to later distinguish between treated leaves and nontreated new growth. Another set of plants (three replicates) from each species was sprayed with each fungicide at $1 \mathrm{~h}, 1$, 3,5 , and 7 days postinoculation. All of these plants were inoculated at the same time with the same spore suspensions, so only one set of plants of each species was not treated with fungicides (control). For daylily, a replication consisted of a single plant with five to six mature leaves. For geranium and sunflower, a replication consisted of six plants with two and four leaves per plant, respectively. All experiments used a randomized complete block design. The average number of sporulating lesions for each replication was calculated from five to six leaves for daylily, 12 leaves for geraniums, and 24 leaves for sunflowers. Lesions were counted on each leaf of all plants-including both fungicide-treated leaves and nontreated new growth. Disease development was evaluated 12,15 , and 18 days after inoculation for sunflower, daylily, and geranium, respectively. Data were converted to sporulating lesions per $10-\mathrm{cm}$ length of leaf for daylily and to sporulating lesions per whole leaf for geranium and sunflower. All experiments were conducted two or three times.
Data analysis. For each plant species, data for each fungicide timing interval were examined independently, and means from each treatment were analyzed by analysis of variance (ANOVA) using replications and trials as random effects, whereas fungicide treatments were fixed effects. Means were separated by Fisher's protected least significant difference (LSD) with $P=0.05$.

\section{RESULTS}

There were significant differences between trials for the numbers of lesions for each plant type, but there were no significant treatment-by-trial interactions. Therefore, data from each experiment were pooled and combined for analysis.

Daylily. Daylily leaves treated preventatively with fungicides 15 days to $1 \mathrm{~h}$ preinoculation had fewer $(P \leq 0.05)$ lesions than the nontreated control (Table 2). There were no differences among the fungicides in numbers of lesions when fungicides were applied before inoculation. Only azoxystrobin applied $1 \mathrm{~h}$ before inoculation prevented rust development. All fungicides showed curative activity when applied $1 \mathrm{~h}$ after inoculation, and azoxystrobin and the three SBI fungicides exhibited curative activity 1 and 3 days after inoculation (Table 2). Azoxystrobin, propiconazole, and triadimefon had a significant curative effect when applied 5 days postinoculation, but only azoxystrobin significantly reduced lesion number when applied 7 days postinoculation compared with the nontreated control. No difference $(P=0.05)$ was observed in number of lesions between the chlorothalonil treatment applied 1, 3, 5, and 7 days postinoculation compared with the nontreated control (Table 2).

New growth on daylily plants treated 5 days before inoculation with all fungicides had fewer $(P=0.05)$ lesions than new growth on the nontreated check (Table 3 ). Plants treated with azoxystrobin had the fewest lesions on new growth. New growth on plants treated 10 and 15 days before inoculation was not protected by any of the fungicides.

Table 1. Fungicides applied to daylilies, geraniums, and sunflowers to manage rusts

\begin{tabular}{|c|c|c|c|c|c|c|}
\hline $\begin{array}{l}\text { Active } \\
\text { ingredient }\end{array}$ & Trade name & Formulation ${ }^{w}$ & $\begin{array}{c}\text { Rate of } \\
\text { product/liter }^{x}\end{array}$ & Company, city, state & Chemical category $^{w}$ & $\begin{array}{l}\text { Movement } \\
\text { in plant }\end{array}$ \\
\hline Azoxystrobin & Heritage & $50 \mathrm{WDG}$ & $300 \mathrm{mg}$ & $\begin{array}{l}\text { Syngenta Professional Products, } \\
\text { Greensboro, NC }\end{array}$ & Strobilurin & Acropetal \\
\hline Chlorothalonil & Daconil Ultrex & 82.5 WDG & $1,700 \mathrm{mg}$ & Syngenta Professional Products & Broad-spectrum protectant & None \\
\hline Myclobutanil & Systhane & 40 WSP & $300 \mathrm{mg}$ & $\begin{array}{l}\text { Dow AgroSciences LLC, } \\
\text { Indianapolis, IN }\end{array}$ & Sterol biosynthesis inhibitor & Acropetal \\
\hline Propiconazole ${ }^{\mathrm{z}}$ & Banner MAXX & 14.3 MEC & $400 \mu \mathrm{l}$ & Syngenta Professional Products & Sterol biosynthesis inhibitor & Acropetal \\
\hline Triadimefon & Strike & $50 \mathrm{WDG}$ & $300 \mathrm{mg}$ & $\begin{array}{l}\text { Olympic Horticultural Products, } \\
\text { Mainland, PA }\end{array}$ & Sterol biosynthesis inhibitor & Acropetal \\
\hline
\end{tabular}


Geranium. Propiconazole was ineffective at protecting geranium plants when applied before inoculation (Table 4). Plants treated with azoxystrobin, chlorothalonil, myclobutanil, and triadimefon 5 days, 1 day, and $1 \mathrm{~h}$ before inoculation had fewer $(P=0.05)$ lesions per leaf than plants in the nontreated control treatment and those treated with propiconazole (Table 4). In addition, plants treated with azoxystrobin, chlorothalonil, and triadimefon 15 and 10 days before inoculation had fewer lesions than nontreated control plants.

Chlorothalonil was not effective at protecting geranium plants when applied 1 to 7 days after inoculation; however, the other four fungicides provided excellent protection from lesion development when applied up to 7 days after inoculation (Table 4). Too few new geranium leaves were produced during the course of the experiments to determine if new growth was protected by preinoculation fungicide applications.

Sunflower. Plants in all fungicide treatments had fewer $(P=0.05)$ lesions per leaf than those in the nontreated control treatment when fungicides were applied 15 days, 5 days, 1 day, and $1 \mathrm{~h}$ preinoculation; at 10 days preinoculation, only azox- ystrobin, myclobutanil, and chlorothalonil provided significant protection from $P$. helianthi (Table 5). Plants treated with azoxystrobin, myclobutanil, and chlorothalonil from $1 \mathrm{~h}$ to 15 days before inoculation consistently had the fewest lesions. No lesions were formed on plants sprayed with azoxystrobin up to 15 days before inoculation. Plants treated with all five fungicides $1 \mathrm{~h}$ after and 1 day after inoculation were protected from infection, and those treated with azoxystrobin and the two SBI fungicides 5 days postinoculation remained protected (Table 5). When plants were sprayed 7 days after inoculation, only those treated with azoxystrobin had fewer lesions than plants in the nontreated control treatment. Newly emerged, nontreated sunflower leaves on plants treated with azoxystrobin 15 and 10 days before inoculation developed significantly fewer lesions than plants not treated with fungicides or plants treated with the other four fungicides (Table 3). Plants treated with azoxystrobin, chlorothalonil, myclobutanil, and propiconazole, but not triadimefon, had significantly fewer lesions on newly emerged, nontreated leaves of plants sprayed 5 days preinoculation (Table 3 ).

\section{DISCUSSION}

A number of fungicides in several different chemical classes are effective against rusts on ornamental crops $(2,4,6,9,11-13,19,24,26,28,31)$. The five fungicides selected in this study were identified as "effective" or "very effective" in a review of fungicide use on ornamental crops (13). We observed differences in efficacy among the fungicides against three species of Puccinia on three different ornamental crops. All five fungicides used in this study significantly reduced lesion development by $P$. hemerocallidis on daylily when applied as many as 15 days prior to inoculation. When fungicides were applied 15 days before geranium and sunflower plants were inoculated, azoxystrobin reduced disease on both plants while chlorothalonil, myclobutanil, and triadimefon decreased lesion formation on geranium plants. Chlorothalonil, myclobutanil, and propiconazole also reduced disease levels on sunflower leaves. Curative activity was observed on the three rust pathosystems when some products were applied up to 7 days after inoculation (azoxystrobin on all three plants and myclobutanil, propiconazole, and triadimefon

Table 2. Number of rust lesions formed on daylily leaves that were not treated (control) or were treated with fungicides at various intervals both before and after inoculation with urediniospores of Puccinia hemerocallidis

\begin{tabular}{|c|c|c|c|c|c|c|c|c|c|c|}
\hline \multirow[b]{2}{*}{ Treatment $^{\mathrm{w}}$} & \multicolumn{5}{|c|}{ Fungicides applied before inoculation ${ }^{\mathrm{x}}$} & \multicolumn{5}{|c|}{ Fungicides applied after inoculation ${ }^{x}$} \\
\hline & 15 days & 10 days & 5 days & 1 day & $1 \mathrm{~h}$ & $1 \mathrm{~h}$ & 1 day & 3 days & 5 days & 7 days \\
\hline Controly $^{y}$ & $85.8 \mathrm{a}$ & $96.5 \mathrm{a}$ & $60.3 \mathrm{a}$ & $37.7 \mathrm{a}$ & $45.5 \mathrm{a}$ & $114.9 \mathrm{a}$ & $114.9 \mathrm{a}$ & $114.9 \mathrm{a}$ & $114.9 \mathrm{ab}$ & $114.9 a b c$ \\
\hline Azoxystrobin & $10.7 \mathrm{~b}$ & $1.1 \mathrm{~b}$ & $0.1 \mathrm{~b}$ & $0.3 \mathrm{~b}$ & $0.0 \mathrm{~b}$ & $0.1 \mathrm{~b}$ & $0.1 \mathrm{~b}$ & $4.1 \mathrm{~b}$ & $4.1 \mathrm{c}$ & $26.2 \mathrm{~d}$ \\
\hline Chlorothalonil & $9.8 \mathrm{~b}$ & $4.5 \mathrm{~b}$ & $2.8 \mathrm{~b}$ & $1.2 \mathrm{~b}$ & $0.1 \mathrm{~b}$ & $1.0 \mathrm{~b}$ & $114.3 \mathrm{a}$ & $124.5 \mathrm{a}$ & $150.1 \mathrm{a}$ & $145.6 \mathrm{a}$ \\
\hline Myclobutanil & $21.2 \mathrm{~b}$ & $18.3 \mathrm{~b}$ & $0.3 \mathrm{~b}$ & $2.0 \mathrm{~b}$ & $1.0 \mathrm{~b}$ & $1.1 \mathrm{~b}$ & $10.3 \mathrm{~b}$ & $5.6 \mathrm{~b}$ & $92.1 \mathrm{~b}$ & $121.4 \mathrm{ab}$ \\
\hline Propiconazole & $22.1 \mathrm{~b}$ & $16.0 \mathrm{~b}$ & $4.6 \mathrm{~b}$ & $0.7 \mathrm{~b}$ & $0.7 \mathrm{~b}$ & $0.1 \mathrm{~b}$ & $0.1 \mathrm{~b}$ & $0.1 \mathrm{~b}$ & $4.1 \mathrm{c}$ & $90.8 \mathrm{bc}$ \\
\hline Triadimefon & $24.5 \mathrm{~b}$ & $4.9 \mathrm{~b}$ & $0.6 \mathrm{~b}$ & $0.5 \mathrm{~b}$ & $0.2 \mathrm{~b}$ & $0.6 \mathrm{~b}$ & $0.1 \mathrm{~b}$ & $0.1 \mathrm{~b}$ & $0.5 \mathrm{c}$ & $70.1 \mathrm{~cd}$ \\
\hline $\mathrm{LSD}^{\mathrm{z}}$ & 26.9 & 25.0 & 10.7 & 13.8 & 11.3 & 42.6 & 72.9 & 53.3 & 57.4 & 54.1 \\
\hline
\end{tabular}

${ }^{\mathrm{w}}$ All plants were inoculated with a urediniospore suspension ( 2 to $4 \times 10^{5}$ spores per milliliter). Control plants received no fungicide application and fungicides were applied at label rates.

${ }^{x}$ Values are the mean number of sporulating lesions per 10-cm length of leaf and were calculated from three replications (five to six mature leaves per replication) in each of three trials conducted in a greenhouse. Data were collected 15 days after inoculation.

y All postinoculation treatments are compared with one set of three replications of nontreated (control) plants.

${ }^{\mathrm{z}}$ Data for each interval were analyzed by one-way analysis of variance, and means separated by Fisher's protected least significant difference (LSD) with $P$ $=0.05$.

Table 3. Number of rust lesions formed on noninoculated new leaves that developed after fungicide treatments were applied either 5 , 10, or 15 days before inoculation of daylily and sunflower plants

\begin{tabular}{|c|c|c|c|c|c|c|}
\hline \multirow[b]{2}{*}{ Treatment $^{w}$} & \multicolumn{3}{|c|}{ Daylily $^{x}$} & \multicolumn{3}{|c|}{ Sunflower $^{y}$} \\
\hline & 5 days & 10 days & 15 days & 5 days & 10 days & 15 days \\
\hline Control & $106.0 \mathrm{a}$ & 128.7 & 146.1 & $28.6 \mathrm{a}$ & $98.8 \mathrm{ab}$ & $158.5 \mathrm{a}$ \\
\hline Azoxystrobin & $11.9 \mathrm{c}$ & 93.9 & 125.9 & $0.0 \mathrm{~d}$ & $0.2 \mathrm{c}$ & $32.7 \mathrm{~b}$ \\
\hline Chlorothalonil & $29.2 \mathrm{bc}$ & 67.8 & 121.3 & $5.3 \mathrm{~cd}$ & $97.5 \mathrm{ab}$ & $135.4 \mathrm{a}$ \\
\hline Myclobutanil & $35.7 \mathrm{bc}$ & 132.9 & 133.1 & $15.9 \mathrm{bc}$ & $70.7 \mathrm{~b}$ & $106.9 \mathrm{a}$ \\
\hline Propiconazole & $56.7 \mathrm{~b}$ & 126.3 & 124.8 & $13.4 \mathrm{bc}$ & $100.9 \mathrm{ab}$ & $136.6 \mathrm{a}$ \\
\hline Triadimefon & $25.4 \mathrm{bc}$ & 80.9 & 111.4 & $22.2 \mathrm{ab}$ & $132.2 \mathrm{a}$ & $159.2 \mathrm{a}$ \\
\hline $\mathrm{LSD}^{\mathrm{z}}$ & 38.4 & ns & ns & 10.7 & 54.4 & 53.7 \\
\hline
\end{tabular}

${ }^{\mathrm{w}}$ All plants were inoculated with a urediniospore suspension ( 2 to $4 \times 10^{5}$ spores per milliliter). Control plants received no fungicide application and fungicides were applied at label rates.

${ }^{\mathrm{x}}$ Values are the mean number of sporulating lesions per $10-\mathrm{cm}$ length of leaf and were calculated from three replications (one to three mature leaves per replication) in each of three trials conducted in a greenhouse. Data were collected 15 and 12 days postinoculation for daylily and sunflower plants, respectively.

y Values are the mean number of sporulating lesions per leaf and were calculated from three replications (two leaves per plant and six plants per replication) in each of two trials conducted in a greenhouse.

${ }^{\mathrm{z}}$ Data for each interval were analyzed by one-way analysis of variance, and means separated by Fisher's protected least significant difference (LSD) with $P$ $=0.05 ; \mathrm{ns}=$ means are not significantly different. 
on geranium). In general, efficacy of most of the fungicides decreased as the time from application to inoculation (preventative properties) or inoculation to application (curative properties) increased.

Applications of fungicides should be timed to optimize the potential deleterious effect of the fungicide on the pathogen. The ability to apply fungicides near the time of infection in a noncontrolled environment rarely happens, since rust epidemics often include a continuum of infection cycles (created by spores coming from new to old lesions) and product labels limit the frequency of application for many fungicides. This limits the usefulness of fungicide data from studies that apply fungicides immediately before or after inoculating plants. For example, triadimefon is considered an effective fungicide for rusts on ornamental crops (13). When applied 1 day prior to inoculation, triadimefon completely eliminated development of Uromyces dianthi on carnation (26). However, when triadimefon was applied 7 days before, 1 day after, 2 days after, and 7 days after inoculation, rust incidence was still $60 \%$ on fungicide-treated plants compared with $100 \%$ on nontreated control plants (26). In our study, triadimefon significantly limited lesion development by $P$. hemerocallidis on daylily and $P$. pelargoniizonalis on geranium at all application times. Triadimefon was not as efficacious against $P$. helianthi on sunflower when applied 10 days preinoculation or 3 to 7 days postinoculation.

The four systemic fungicides used in this study displayed some curative activity against all three rusts. Curative activity of triadimefon against $P$. pelargonii-zonalis on geranium also was observed by Gjaerum (9). Lesion development was halted and necrotic zones formed around the sori (9). Myclobutanil (2) and propiconazole (6) displayed strong curative qualities against $P$. horiana on chrysanthemum. A significant finding in our study was that several fungicides displayed curative action when applied 5 to 7 days after inoculation. Most of the fungicides tested were effective up to 5 days postinoculation for daylily and sunflower rusts, while they were effective up to 7 days postinoculation for geranium rust. We suggest that one limiting factor for observing the potential curative properties of a fungicide may be the length of time between infection and sporulation of the target rust pathogen and when the fungicide is applied to the in- fected host. In the present study, lesions of daylily and sunflower rust developed faster after infection than lesions of geranium rust. Sporulating lesions were first observed 8 to 9 days, 10 to 12 days, and 13 to 15 days after inoculation on the sunflower, daylily, and geranium plants, respectively, used in this study.

When implementing a fungicide program to manage rusts, one also needs to be cognizant of the potential for development of resistance in the target population. Little research on fungicide efficacy has been published for daylily and geranium rusts $(4,11,12)$, and so far, no reports of fungicide-resistant strains of these pathogens have been reported. No differences were observed in the sensitivity of 11 isolates of $P$. hemerocallidis to various fungicides using an in vitro agar assay (D. S. Mueller and J. W. Buck, unpublished data). Fungicide resistance has been reported for other species of Puccinia, such as $P$. horiana $(5,7)$.

Oxycarboxin was introduced in the late 1960s, and a related compound, benodanil, was introduced in the mid 1970s. Both of these products initially provided excellent control of chrysanthemum white rust $(7,9)$, but by the early 1980s, strains of this

Table 4. Number of rust lesions formed on geranium leaves that were not treated (control) or were treated with fungicides at various intervals both before and after inoculation with urediniospores of Puccinia pelargonii-zonalis

\begin{tabular}{|c|c|c|c|c|c|c|c|c|c|c|}
\hline \multirow[b]{2}{*}{ Treatment $^{w}$} & \multicolumn{5}{|c|}{ Fungicides applied before inoculation ${ }^{x}$} & \multicolumn{5}{|c|}{ Fungicides applied after inoculation ${ }^{x}$} \\
\hline & 15 days & 10 days & 5 days & 1 day & $1 \mathrm{~h}$ & $1 \mathrm{~h}$ & 1 day & 3 days & 5 days & 7 days \\
\hline Controly & $7.8 \mathrm{~b}$ & $10.2 \mathrm{~b}$ & $19.8 \mathrm{a}$ & $21.2 \mathrm{a}$ & $12.2 \mathrm{a}$ & $47.1 \mathrm{a}$ & $47.1 \mathrm{a}$ & $47.1 \mathrm{a}$ & $47.1 \mathrm{a}$ & $47.1 \mathrm{a}$ \\
\hline Azoxystrobin & $0.2 \mathrm{~d}$ & $0.2 \mathrm{~d}$ & $0.0 \mathrm{~b}$ & $0.0 \mathrm{~b}$ & $0.0 \mathrm{~b}$ & $0.0 \mathrm{~b}$ & $0.0 \mathrm{~b}$ & $0.0 \mathrm{~b}$ & $0.0 \mathrm{~b}$ & $1.3 \mathrm{c}$ \\
\hline Chlorothalonil & $1.7 \mathrm{~cd}$ & $0.3 \mathrm{~d}$ & $0.0 \mathrm{~b}$ & $0.0 \mathrm{~b}$ & $0.0 \mathrm{~b}$ & $0.0 \mathrm{~b}$ & $29.3 \mathrm{a}$ & $43.1 \mathrm{a}$ & $33.5 \mathrm{a}$ & $25.0 \mathrm{~b}$ \\
\hline Myclobutanil & $5.1 \mathrm{bc}$ & $6.8 \mathrm{bc}$ & $0.7 \mathrm{~b}$ & $0.2 \mathrm{~b}$ & $0.0 \mathrm{~b}$ & $0.0 \mathrm{~b}$ & $0.0 \mathrm{~b}$ & $0.0 \mathrm{~b}$ & $0.0 \mathrm{~b}$ & $0.1 \mathrm{c}$ \\
\hline Propiconazole & $12.4 \mathrm{a}$ & $18.1 \mathrm{a}$ & $22.1 \mathrm{a}$ & $18.8 \mathrm{a}$ & $11.3 \mathrm{a}$ & $1.8 \mathrm{~b}$ & $3.0 \mathrm{~b}$ & $0.9 \mathrm{~b}$ & $2.5 \mathrm{~b}$ & $6.3 \mathrm{bc}$ \\
\hline Triadimefon & $3.3 \mathrm{~cd}$ & $2.8 \mathrm{~cd}$ & $0.6 \mathrm{~b}$ & $0.3 \mathrm{~b}$ & $0.4 \mathrm{~b}$ & $0.0 \mathrm{~b}$ & $0.6 \mathrm{~b}$ & $1.5 \mathrm{~b}$ & $0.2 \mathrm{~b}$ & $4.4 \mathrm{c}$ \\
\hline $\mathrm{LSD}^{\mathrm{z}}$ & 4.0 & 5.8 & 8.7 & 16.0 & 4.0 & 21.2 & 24.2 & 26.7 & 23.8 & 20.5 \\
\hline
\end{tabular}

${ }^{w}$ All plants were inoculated with a urediniospore suspension ( 2 to $4 \times 10^{5}$ spores per milliliter). Control plants received no fungicide application and fungicides were applied at label rates.

x Values are the mean number of sporulating lesions per leaf and were calculated from three replications (two leaves per plant and six plants per replication) in each of two trials conducted in a greenhouse. Data were collected 18 days after inoculation.

y All postinoculation treatments are compared with one set of three replications of nontreated (control) plants.

${ }^{\mathrm{z}}$ Data for each interval were analyzed by one-way analysis of variance, and means separated by Fisher's protected least significant difference (LSD) with $P$ $=0.05$.

Table 5. Number of rust lesions formed on sunflower leaves that were not treated (control) or were treated with fungicides at various intervals both before and after inoculation with urediniospores of Puccinia helianthi

\begin{tabular}{|c|c|c|c|c|c|c|c|c|c|c|}
\hline \multirow[b]{2}{*}{ Treatment $^{w}$} & \multicolumn{5}{|c|}{ Fungicides applied before inoculation ${ }^{x}$} & \multicolumn{5}{|c|}{ Fungicides applied after inoculation ${ }^{x}$} \\
\hline & 15 days & 10 days & 5 days & 1 day & $1 \mathbf{h}$ & $1 \mathbf{h}$ & 1 day & 3 days & 5 days & 7 days \\
\hline Controly $^{\mathrm{y}}$ & $111.1 \mathrm{a}$ & $78.2 \mathrm{a}$ & $46.6 \mathrm{a}$ & $43.7 \mathrm{a}$ & $30.9 \mathrm{a}$ & $67.0 \mathrm{a}$ & $67.0 \mathrm{a}$ & $67.0 \mathrm{a}$ & $67.0 \mathrm{a}$ & $67.0 \mathrm{a}$ \\
\hline Azoxystrobin & $0.0 \mathrm{c}$ & $0.0 \mathrm{c}$ & $0.0 \mathrm{c}$ & $0.0 \mathrm{c}$ & $0.0 \mathrm{~b}$ & $0.0 \mathrm{~b}$ & $0.0 \mathrm{~b}$ & $0.0 \mathrm{~b}$ & $0.1 \mathrm{~b}$ & $3.8 \mathrm{~b}$ \\
\hline Chlorothalonil & $22.4 \mathrm{bc}$ & $10.6 \mathrm{bc}$ & $8.7 \mathrm{bc}$ & $1.7 \mathrm{c}$ & $2.6 \mathrm{~b}$ & $1.2 \mathrm{~b}$ & $68.0 \mathrm{a}$ & $71.0 \mathrm{a}$ & $82.2 \mathrm{a}$ & $70.8 \mathrm{a}$ \\
\hline Myclobutanil & $20.0 \mathrm{bc}$ & $9.1 \mathrm{c}$ & $2.5 \mathrm{c}$ & $0.2 \mathrm{c}$ & $0.1 \mathrm{~b}$ & $0.0 \mathrm{~b}$ & $0.0 \mathrm{~b}$ & $0.1 \mathrm{~b}$ & $2.9 \mathrm{~b}$ & $44.4 \mathrm{ab}$ \\
\hline Propiconazole & $25.1 \mathrm{bc}$ & $46.3 \mathrm{ab}$ & $5.6 \mathrm{bc}$ & $3.0 \mathrm{c}$ & $3.8 \mathrm{~b}$ & $0.1 \mathrm{~b}$ & $0.0 \mathrm{~b}$ & $0.0 \mathrm{~b}$ & $0.6 \mathrm{~b}$ & $78.2 \mathrm{a}$ \\
\hline Triadimefon & $58.5 \mathrm{~b}$ & $72.1 \mathrm{a}$ & $16.2 \mathrm{~b}$ & $20.5 b$ & $3.3 \mathrm{~b}$ & $3.6 \mathrm{~b}$ & $4.5 \mathrm{~b}$ & $28.1 \mathrm{ab}$ & $88.9 \mathrm{a}$ & $77.7 \mathrm{a}$ \\
\hline $\mathrm{LSD}^{\mathrm{z}}$ & 42.2 & 36.1 & 13.3 & 17.3 & 6.3 & 48.3 & 50.0 & 48.8 & 54.4 & 47.5 \\
\hline
\end{tabular}

${ }^{w}$ All plants were inoculated with a urediniospore suspension ( 2 to $4 \times 10^{5}$ spores per milliliter). Control plants received no fungicide application and fungicides were applied at label rates.

$\mathrm{x}$ Values are the mean number of sporulating lesions per leaf and were calculated from three replications (four leaves per plant and six plants per replication) in each of two trials conducted in a greenhouse. Data were collected 12 days after inoculation.

y All postinoculation treatments are compared to one set of three replications of nontreated (control) plants.

z Data for each interval were analyzed by one-way analysis of variance, and means separated by Fisher's protected least significant difference (LSD) with $P$ $=0.05$. 
pathogen less sensitive to these fungicides were found (7). During the last two decades, numerous reports have shown that triazole (e.g., myclobutanil and propiconazole) $(2,6,19,24)$ and strobilurin compounds (e.g., azoxystrobin and kresoximmethyl) $(24,31)$ controlled chrysanthemum white rust. In a report from England in 2001, strains of $P$. horiana were found to be insensitive to both triazole and strobilurin fungicides (5). This exemplifies the need for proper management of fungicide use to ensure $P$. hemerocallidis and $P$. pelargonii-zonalis remain sensitive to triazole and strobilurin fungicides.

Additional factors will impact the efficacy of both contact and systemic fungicides, including rate of new plant growth, temperature, and the amount and frequency of rainfall or irrigation. With plants that were actively growing, the fungicides tested in this study did not protect new growth on either daylily or sunflower when applied 15 days prior to inoculation, with the exception of azoxystrobin sprayed on sunflower. The effect of rainfall or irrigation on efficacy when fungicides are applied before inoculation was not addressed in the current study. Rainfall or irrigation can remove fungicides from plant foliage, but this depends on the type of fungicide, leaf physical factors, the duration between fungicide application and a water event, and the ambient environmental conditions that affect drying $(3,8,23)$. Manufacturers recommend a rainfall/irrigation-free period of at least several hours after application to ensure proper protection because wet spray deposits on leaf surfaces are much more vulnerable to removal than those that have dried. Systemic fungicides are presumably less affected by weathering than surfaceactive protectant fungicides, but adequate time and favorable environmental conditions for uptake and absorption are required. For example, triadimefon is not supposed to be affected by rainfall or irrigation $30 \mathrm{~min}$ after application (2003 Strike Specimen Label, Olympic Horticultural Products Co., Mainland, PA), presumably because it has entered the plant tissues. Removal of a protectant fungicide by rain or irrigation can reduce efficacy. Fungicides also can degrade or become diluted on/in plant surfaces as indicated by the increase in disease incidence in this study when preventative applications were applied from $1 \mathrm{~h}$ to 15 days preinoculation.

In the present study, the efficacy of each fungicide was determined by assessing the numbers of lesions that developed in each rust pathosystem, which is just one method to quantify efficacy. Fungicides, particularly systemic fungicides, can affect pathogenesis and subsequent disease development in other ways. Consequently, the effects of fungicides on production and viability of urediniospores currently are being investigated for each of the three rust pathosystems used in this study. Eventually, we hope to develop a better understanding of the efficacy of fungicides against rust pathogens of ornamental crops so that appropriate recommendations for effective disease management can be made.

\section{ACKNOWLEDGMENTS}

We thank M. Case, R. Estes, and K. Wise for technical assistance; T. Gulya for an isolate of $P$. helianthi and sunflower seed; McCorkle's Nursery in Dearing, GA, for daylily plants; and Goldsmith Seeds, Inc. for geranium seed.

\section{LITERATURE CITED}

1. Bhowmik, T. P., and Singh, A. 1979. Evaluation of certain fungitoxicants for the control of sunflower rust. Indian Phytopathol. 32:443444.

2. Bonde, M. R., Peterson, G. L., Rizvi, S. A., and Smilanick, J. L. 1995. Myclobutanil as a curative agent for chrysanthemum white rust. Plant Dis. 79:500-505.

3. Bruhn, J. A., and Fry, W. E. 1982. A mathematical model of the spatial and temporal dynamics of chlorothalonil residues on potato foliage. Phytopathology 72:1306-1312.

4. Buck, J. W., and Williams-Woodward, J. L. 2003. The effect of fungicides on urediniospore germination and disease development of daylily rust. Crop Prot. 22:135-140.

5. Cook, R. T. A. 2001. First report in England of changes in the susceptibility of Puccinia horiana, the cause of chrysanthemum white rust, to triazole and strobilurin fungicides. Plant Pathol. 50:792.

6. Dickens, J. S. W. 1990. Studies on the chemical control of chrysanthemum white rust caused by Puccinia horiana. Plant Pathol. 39:434-442.

7. Dirkse, F. B., Dil, M., Linders, R., and Rietstra, I. 1982. Resistance in white rust (Puccinia horiana P. Hennings) of chrysanthemum to oxycarboxin and benodanil in the Netherlands. Meded. Fac. Landbouwwet. Rijksuniversiteit Gent 47:793-800.

8. Fife, J. P., and Nokes, S. E. 2002. Evaluation of the effect of rainfall intensity and duration on the persistence of chlorothalonil on processing tomato foliage. Crop Prot. 21:733-740.

9. Gjaerum, H. B. 1979. Rustsopper pa veksthuskulturer (Translated: Rust fungi on glasshouse crops). Forsk. Fors. Landbruket 30:91-109.

10. Gulya, T., Venette, R., Venette, J. R., and Lamey, H. A. 1990. Sunflower rust. NDSU Extension Service. North Dakota State University, Fargo. p. 998.

11. Harwood, C. A., and Raabe, R. D. 1979. The disease cycle and control of geranium rust. Phytopathology 69:923-927.

12. Jeffers, S. N., and Luszcz, L. A. 1998. Controlling rust on zonal geraniums with fungicides. Proc. Southern Nursery Assoc. Res. Conf. 43:228-232.

13. Jeffers, S. N., Miller, R. W., and Powell, C. C. 2001. Fungicides for ornamental crops in the nursery. Pages 409-416 in: Diseases of Woody Ornamentals and Trees in Nurseries. R. K. Jones and D. M. Benson, eds. American Phy- topathological Society, St. Paul, MN.

14. Jerardo, A. 2003. Floriculture and nursery crops situation and outlook yearbook. Market and Trade Economics Division, U.S. Dep. Agric. Econ. Res. Serv. June 2003. Online Resources.

15. Jones, R. K., Simone, G. W., von Broembsen, S. L., and Dutky, E. 2001. Integrated disease management. Pages 376-383 in: Diseases of Woody Ornamentals and Trees in Nurseries. R. K. Jones and D. M. Benson, eds. American Phytopathological Society, St. Paul, MN

16. Kontaxis, D. G. 1986. Managing powdery mildew and rust on sunflower. Cal. Agric 40:18.

17. Kuck, K. H., Scheinpflug, H., and Pontzen, R. 1995. DMI fungicides. Pages $205-258$ in Modern Selective Fungicides: Properties, Applications, Mechanisms of Action. 2nd ed. $\mathrm{H}$. Lyr, ed. Gustav Fischer Verlag, New York.

18. Lal, B. B., and Singh, R. D. 1977. Control of sunflower rust by pre- and post-infection spraying of systemic and non-systemic fungicides. Pesticides 11:24-25.

19. Lam, C. H., and Lim, T. K. 1993. Efficacy of hexaconazole for the control of white rust on chrysanthemum and powdery mildew on roses. Int. J. Pest Manag. 39:156-160.

20. Mathur, S., Lal Thakore, B. B., Singh, R. B. and Chakravarti, B. P. 1980. Comparative efficacy of systemic and nonsystemic fungicides for the control of rust of sunflower. Pestology 4:35-36.

21. Mueller, D. S., and Buck, J. W. 2003. Effects of light, temperature, and leaf wetness duration on daylily rust. Plant Dis. 87:442-445.

22. Mueller, D. S., Williams-Woodward, J. L., and Buck, J. W. 2003. Resistance of daylily cultivars to the daylily rust pathogen, Puccinia hemerocallidis. HortScience 38:1137-1140.

23. Neely, D. 1970. Persistence of foliar protective fungicides. Phytopathology 60:1583-1586.

24. O'Neill, T. M., and Pye, D. 1997. Evaluation of fungicides for control of chrysanthemum white rust (Puccinia horiana). Ann. Appl. Biol. (Suppl.) 18:8-9.

25. Singh, R. D., and Lal, B. B. 1978. Efficacy of certain selected fungicides for the control of sunflower rust. Indian Phytopathol. 31:525527.

26. Spencer, D. M. 1979. Carnation rust and its control by systemic fungicides. Plant Pathol. 28:10-16.

27. U.S. Department of Agriculture, Animal and Plant Health Inspection Service. 2003. APHIS Regulated Pest List. Washington, DC. Online publication.

28. Weber, R. W. S., and Tilston, E. L. 1999. Evaluation of three rust-controlling fungicides for control of daisy rust (Puccinia distincta) under greenhouse conditions. Ann. Appl. Biol. (Suppl.) 134:16-17.

29. Whipps, J. M. 1993. A review of white rust (Puccinia horiana Henn.) disease on chrysanthemum and the potential for its biological control with Verticillium lecanii (Zimm.) Viégas. Ann. Appl. Biol. 122:173-187.

30. Williams-Woodward, J. L., Hennen, J. F., Parda, K. W., and Fowler, J. M. 2001. First report of daylily rust in the United States. Plant Dis. 85:1121.

31. Wojdyyla, A. T., and Orlikowski, L. B. 1999. Strobilurin compounds in control of rust, powdery mildew and black spot on some ornamental plants. Meded. Fac. Landbouwk. Toegepaste Biol. Wetenschappen Univ. Gent 64:539-545. 